\title{
SEISMIC ANALYSIS OF MULTISTORIED IRREGULAR AND REGULAR BUILDING WITH MASONARY INFILLS
}

\author{
Ashutosh Shrivastava \\ Civil Engineering Department \\ IPS Academy, \\ Institute of Engineering and Science, \\ Indore, M.P. India
}

Abstract - Nowadays, as in the urban areas the space available for the construction of buildings is limited. So in limited space we have to construct such type of buildings which can be used for multiple purposes such as lobbies, car parking etc. To fulfill this demand, high rise buildings is the only option available. The performance of a high rise building during strong earthquake motion depends on the distribution of stiffness, strength and mass along both the vertical and horizontal directions. If there is discontinuity in stiffness, strength and mass between adjoining storeys of a building then such a building is known as irregular building. The present study focuses on the seismic performance of regular and vertical irregular building with and without masonary infills. In the present study G+11 building is considered for the analysis with modelling and analysis done on ETABS software v17.0.1. The earthquake forces are calculated as per IS 1893 (part 1): 2016 for seismic zone III. The width of strut is calculated by using equivalent diagonal strut method. Total five models are considered for the analysis i.e. regular building with bare frame, regular building with masonary infill, soft storey building with open ground storey, mass irregular building with masonary infill and vertical geometric irregular building with masonary infill. The non-linear static analysis (pushover analysis) and linear dynamic analysis (response spectrum analysis) are performed for all the models and thereby compare their results. From analysis, the parameters like performance point, time period, maximum storey displacement, maximum storey drifts, storey shears and overturning moments are determined and also comparative study is done for all the models. From the comparison, it is observed that the vertical geometric irregular building shows better performance under seismic loading and bare frame building shows inferior performance. Moreover, the performance of masonary infilled frame building is found better than the bare frame building. So it is essential to consider the effect of masonry infill for the seismic evaluation of moment resisting reinforced concrete frame.

\author{
Rajesh Chaturvedi \\ Civil Engineering Department \\ IPS Academy, \\ Institute of Engineering and Science, \\ Indore, M.P. India
}

Keywords - Masonary Infill, Regular and Irregular Building, Equivalent Diagonal Strut, Pushover Analysis, Response Spectrum Analysis.

\section{INTRODUCTION}

Seismic analysis is a subset of structural analysis and is the calculation of the response of a building (or nonbuilding) structure to earthquakes. It is part of the process of structural design, earthquake engineering or structural assessment and retrofit in regions where earthquakes are prevalent. Earthquake engineering has developed a lot since the early days, and some of the more complex designs now use special earthquake protective elements either just in the foundation or distributed throughout the structure. Analyzing these types of structures requires specialized explicit finite element computer code. Structural analysis is the determination of the effects of loads on physical structures and their components. Structures subject to this type of analysis include all that must withstand loads, such as buildings, bridges, vehicles, furniture, attire, soil strata, etc. Structural analysis employs the fields of applied mechanics, materials science and applied mathematics to compute a structure's deformations, internal forces, stresses, support reactions, accelerations, and stability. The results of the analysis are used to verify a structure's fitness for use, often precluding physical tests. Structural analysis is thus a key part of the engineering design of structures. This paper presents non-linear static and linear dynamic analysis of G+11 multistoried building analyzed as per IS 1893(Part-1): 2016. The objective of this study is to perform pushover analysis and response spectrum analysis of regular and irregular buildings with and without infill and there by obtain and compare results.

The results are presented in terms of performance point, time period, maximum storey displacement, maximum storey drifts, storey shears and overturning moments. 


\section{International Journal of Engineering Applied Sciences and Technology, 2021 \\ Vol. 5, Issue 12, ISSN No. 2455-2143, Pages 112-121 \\ Published Online April 2021 in IJEAST (http://www.ijeast.com)}

\section{METHODOLOGY}

A reinforced concrete building with $\mathrm{G}+11$ storey has been taken for seismic analysis. Five building models are considered for comparison. All considered models are symmetrical in plan with two models are regular and three models having vertical irregularity. Four models are modeled with masonary infills and one without infills. The typical plan dimension of the buildings in $\mathrm{X}$ direction length: $31.5 \mathrm{~m}$ and $\mathrm{Y}$ direction width: $31.5 \mathrm{~m}$ which is divided into 7 bay in each direction. Total height of the building is $39.6 \mathrm{~m}$ for all models and for soft storey building is $40.3 \mathrm{~m}$. The stucture is analyzed according to IS 1893(Part-1): 2016 for seismic zone III for soil Class II. Fig. 1 shows plan view of the building.

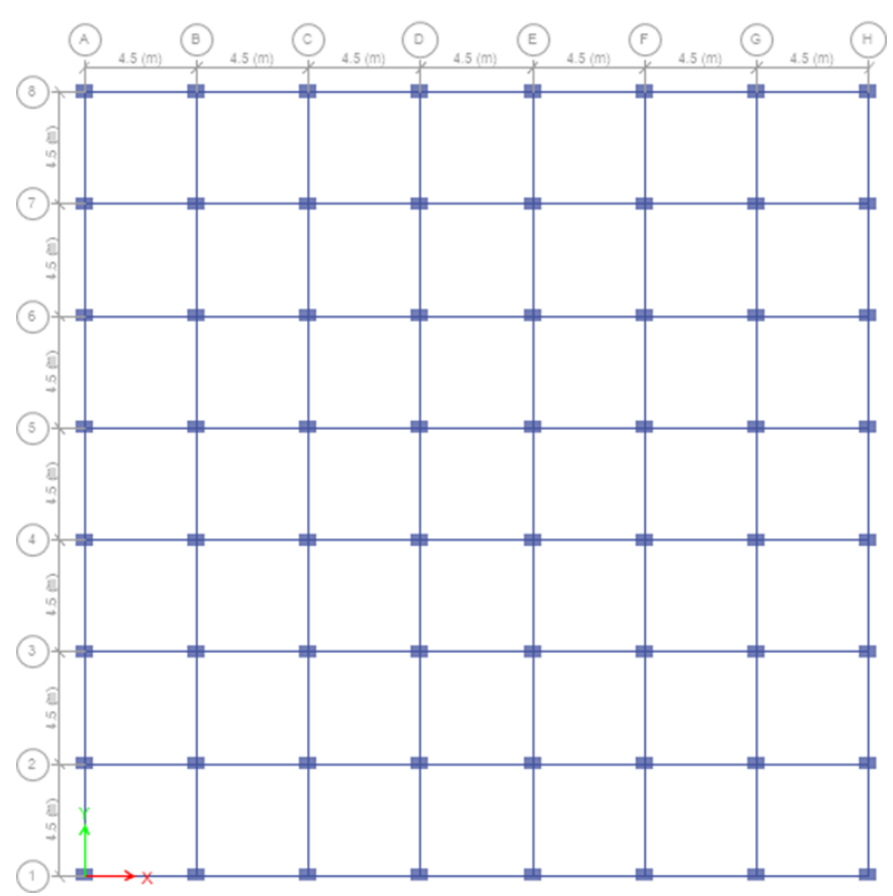

Fig. 1. Plan view of the building

\section{MODELLING PARAMETERS}

\subsection{Description of building}

\begin{tabular}{|c|c|c|}
\hline 1 & Type of building & Public \\
\hline 2 & Plan of the building & Symmetrical \\
\hline 3 & Building plan & $31.5 \mathrm{~m} \times 31.5 \mathrm{~m}$ \\
\hline 4 & Building area & 992.25Sq.m \\
\hline 5 & Total building height & $39.6 \mathrm{~m}$ \\
\hline 6 & Soft storey building height & $40.3 \mathrm{~m}$ \\
\hline 7 & Spacing of frames in both $\mathrm{X}$ directions & $4.5 \mathrm{~m}$ \\
\hline 8 & Spacing of frames in both Y directions & $4.5 \mathrm{~m}$ \\
\hline 9 & Number of bays in the frame in $\mathrm{X}$ direction & 7 \\
\hline 10 & Number of bays in the frame in Y direction & 7 \\
\hline 11 & Each storey height & $3.3 \mathrm{~m}$ \\
\hline 12 & Soft storey ground floor height & $4 \mathrm{~m}$ \\
\hline 13 & Number of storey & $12(\mathrm{G}+11)$ \\
\hline 14 & Grade of concrete & M25 \\
\hline 15 & Grade of steel & $\mathrm{Fe} 500$ \\
\hline 16 & Depth of slab & $150 \mathrm{~mm}$ Thick \\
\hline 17 & Sp. Wt. of Concrete & $24 \mathrm{KN} /$ cubic meter \\
\hline 18 & Sp. Wt. of Steel & $78.5 \mathrm{KN} /$ cubic meter \\
\hline 19 & Beam Size, B1 & $300 \times 500 \mathrm{~mm}$ \\
\hline 20 & Beam Size, B2 & $350 \times 500 \mathrm{~mm}$ \\
\hline 21 & Column Size, C1 & $700 \times 500 \mathrm{~mm}$ \\
\hline 22 & Column Size, C2 & $600 \times 400 \mathrm{~mm}$ \\
\hline 23 & Column Size, C3 & $500 \times 300 \mathrm{~mm}$ \\
\hline 24 & Thickness of exterior wall & $230 \mathrm{~mm}$ \\
\hline 25 & Thickness of interior wall & $100 \mathrm{~mm}$ \\
\hline 26 & Sp. Wt. of Masonary & $18 \mathrm{KN} /$ cubic meter \\
\hline 27 & Modulus of Elasticity of concrete & $25000 \mathrm{MPa}$ \\
\hline 28 & Modulus of Elasticity of masonary & $2186.25 \mathrm{MPa}$ \\
\hline 29 & Shear Modulus of masonary & $1700 \mathrm{MPa}$ \\
\hline 30 & Poisson's ratio of masonary & 0.15 \\
\hline 31 & Compressive strength of masonary prism & $3.98 \mathrm{MPa}$ \\
\hline 32 & Equivalent width of strut & $573 \mathrm{~mm}$ \\
\hline 33 & Dead Load & $3.75 \mathrm{KN} / \mathrm{Sqm}$ \\
\hline 34 & Wt. of flooring / finishing & $1.25 \mathrm{KN} / \mathrm{Sqm}$ \\
\hline 35 & Live Load & $3.00 \mathrm{KN} / \mathrm{Sqm}$ \\
\hline 36 & Wt. of exterior wall & $11.59 \mathrm{KN} / \mathrm{m}$ \\
\hline 37 & Wt. of interior wall & $5.04 \mathrm{KN} / \mathrm{m}$ \\
\hline 38 & Wt. of parapet wall & $4.14 \mathrm{KN} / \mathrm{m}$ \\
\hline 39 & Size of swimming pool & $9 \times 13.5 \mathrm{~m}$ \\
\hline 40 & Swimming pool load for mass irregular building & $20 \mathrm{KN} / \mathrm{Sqm}$ \\
\hline 41 & Zone factor & III \\
\hline 42 & Soil type & II \\
\hline 43 & Importance factor & 1 \\
\hline 44 & Response reduction factor & 5 \\
\hline
\end{tabular}




\subsection{Description of the structure modeled}

A reinforced concrete frame with $\mathrm{G}+11$ storey of dimension $31.5 \mathrm{mx} 31.5 \mathrm{~m}$, has been taken for seismic analysis. Five building models are considered for comparison:

Model 1: Regular building with bare frame

Model 2: Regular building with masonary infill

Model 3: Soft storey building with open ground storey

Model 4: Mass irregular building with masonary infill

Model 5: Vertical geometric irregular building with masonary infill

All five building models are analyzed using nonlinear static analysis and linear dynamic analysis.

Model 1: Regular building with bare frame

In this model, the building geometry is regular and walls are not modeled in this model. Fig. 2 shows elevation of regular building with bare frame.

Model 2: Regular building with masonary infill

In this model, the building geometry is regular and the outer walls are modeled as braced frame. Fig. 3 shows elevation of regular building with masonary infill.

Model 3: Soft storey building with open ground storey

This type of building is stiffness irregular and the ground floor of this building is open and in all floors the outer walls are modeled as braced frame. Moreover, the height of ground storey is greater than all stories. Fig. 4 shows elevation of soft storey building with open ground storey.

Model 4: Mass irregular building with masonary infill

In this type of building, the swimming pool is located at $3 \mathrm{rd}$ and 6th floor and the outer walls are modeled as braced frame in all floors. Fig. 5 shows the location of swimming pool at 3rd and 6th floor. Fig. 6 shows elevation of mass irregular building with masonary infill.
Model 5: Vertical geometric irregular building with masonary infill

In this model, the building geometry is irregular in elevation and the outer walls are modeled as braced frame in all floors. Fig. 7 shows elevation of vertical geometric irregular building with masonary infill.

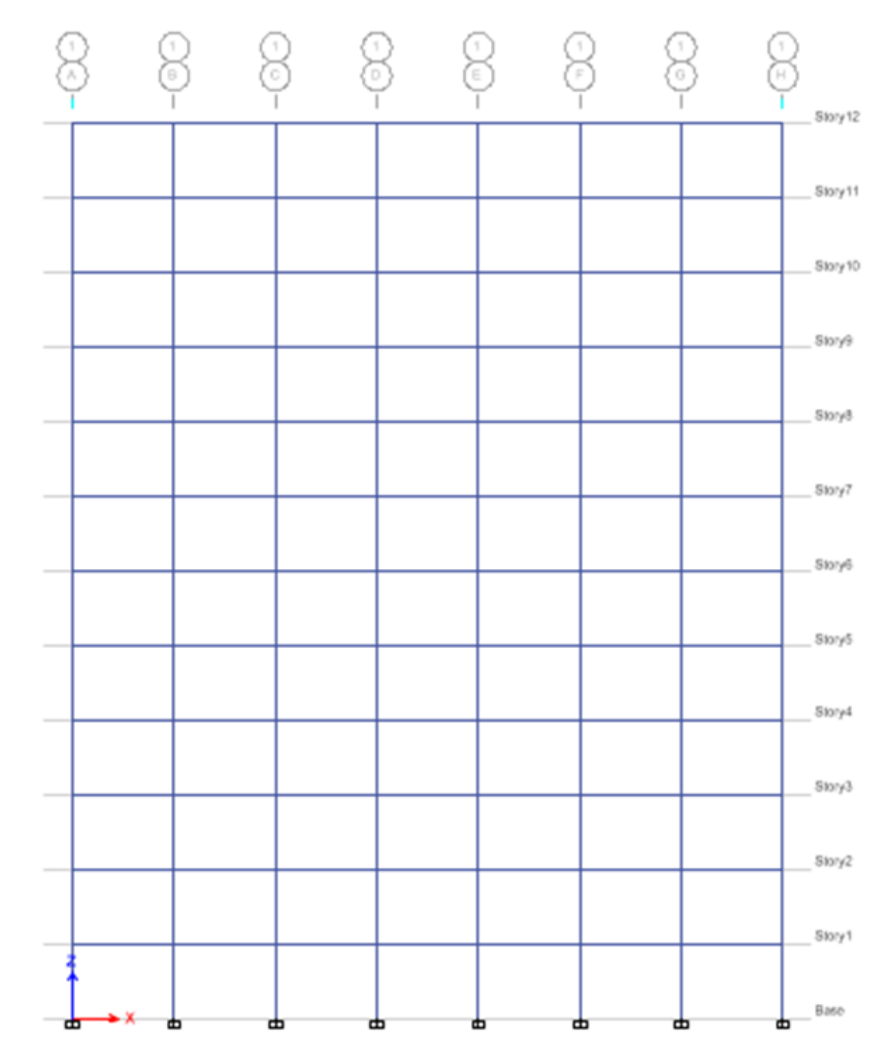

Fig. 2. Elevation of regular building with bare frame 
International Journal of Engineering Applied Sciences and Technology, 2021

Vol. 5, Issue 12, ISSN No. 2455-2143, Pages 112-121

Published Online April 2021 in IJEAST (http://www.ijeast.com)

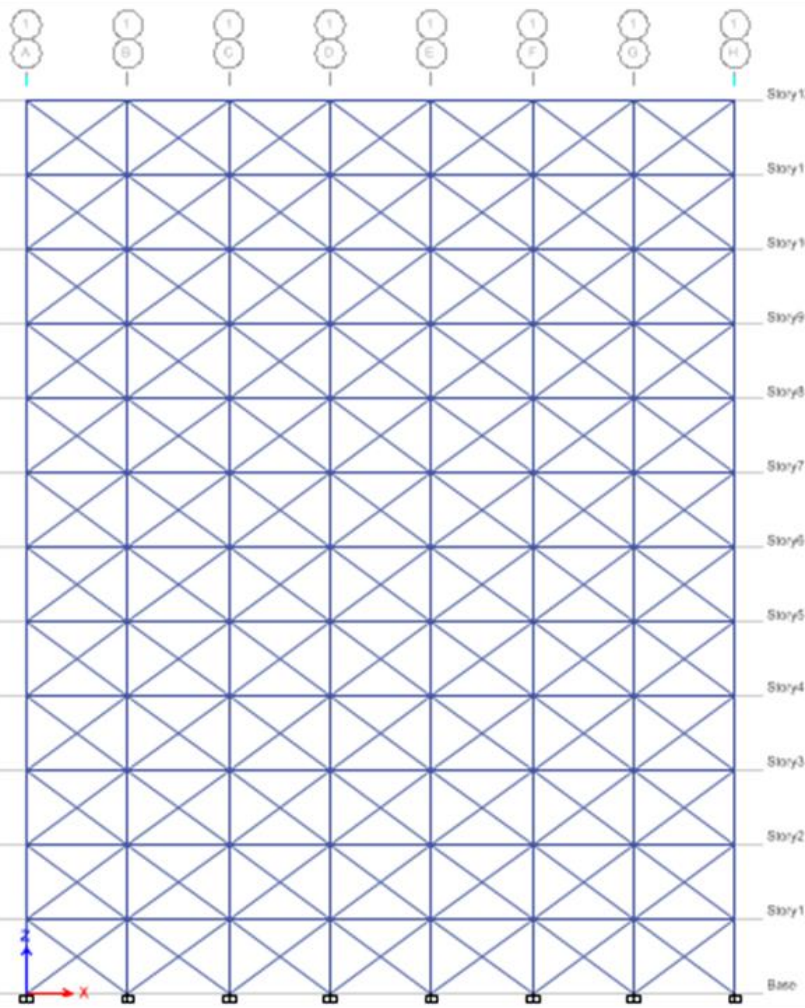

Fig. 3. Elevation of regular building with masonary infill

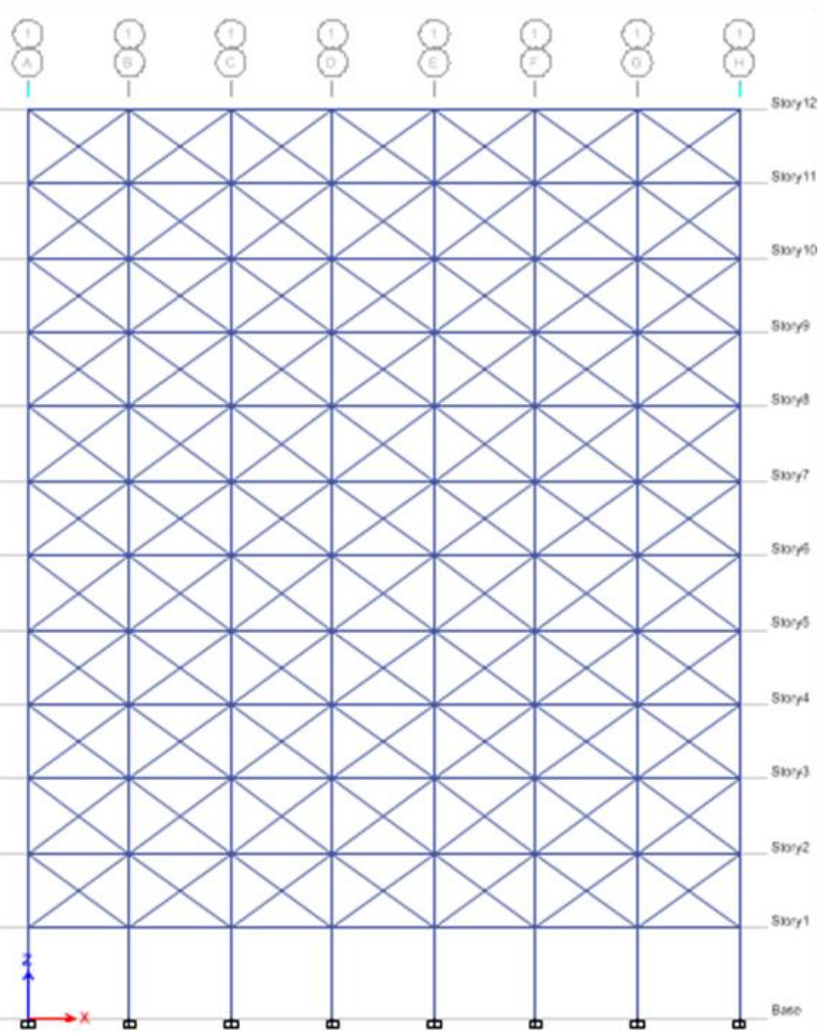

Fig. 4. Elevation of soft storey building with open ground storey

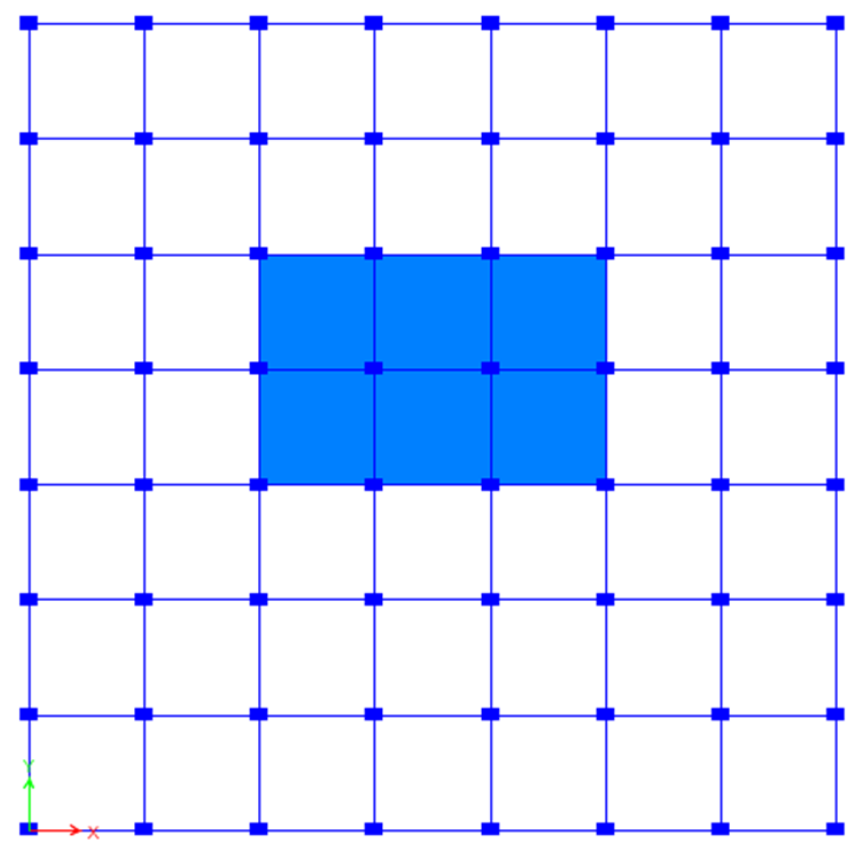

Fig. 5. Location of swimming pool at 3rd and 6th floor in mass irregular building

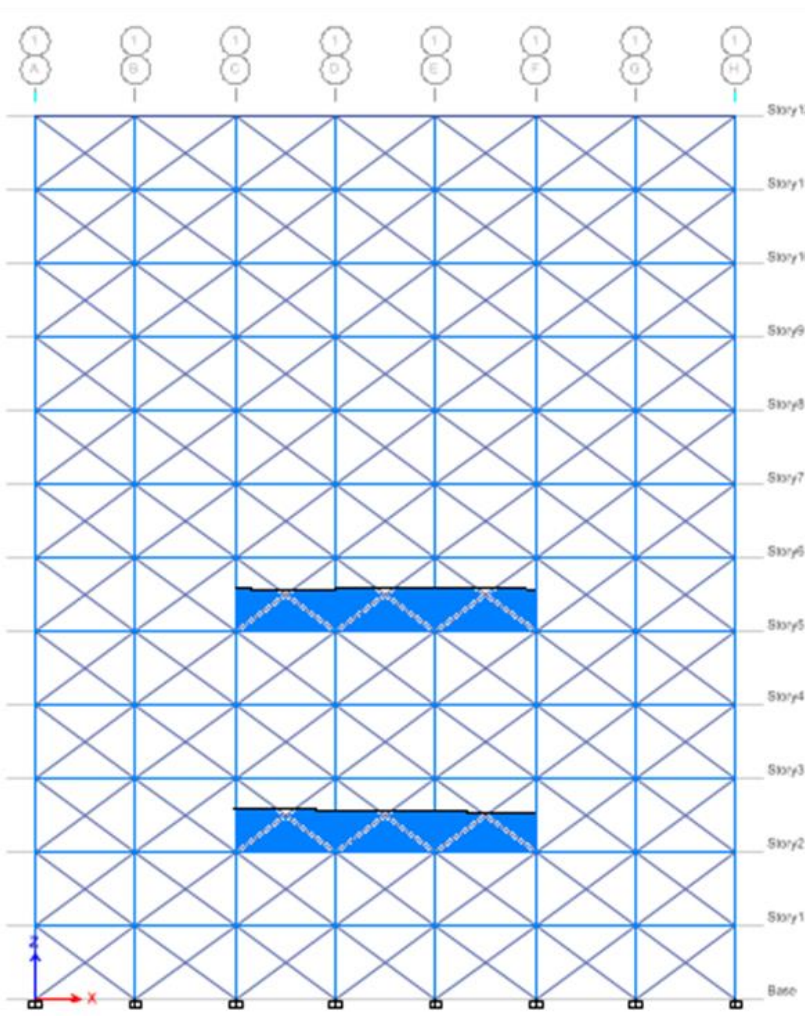

Fig. 6. Elevation of mass irregular building with masonary infill 


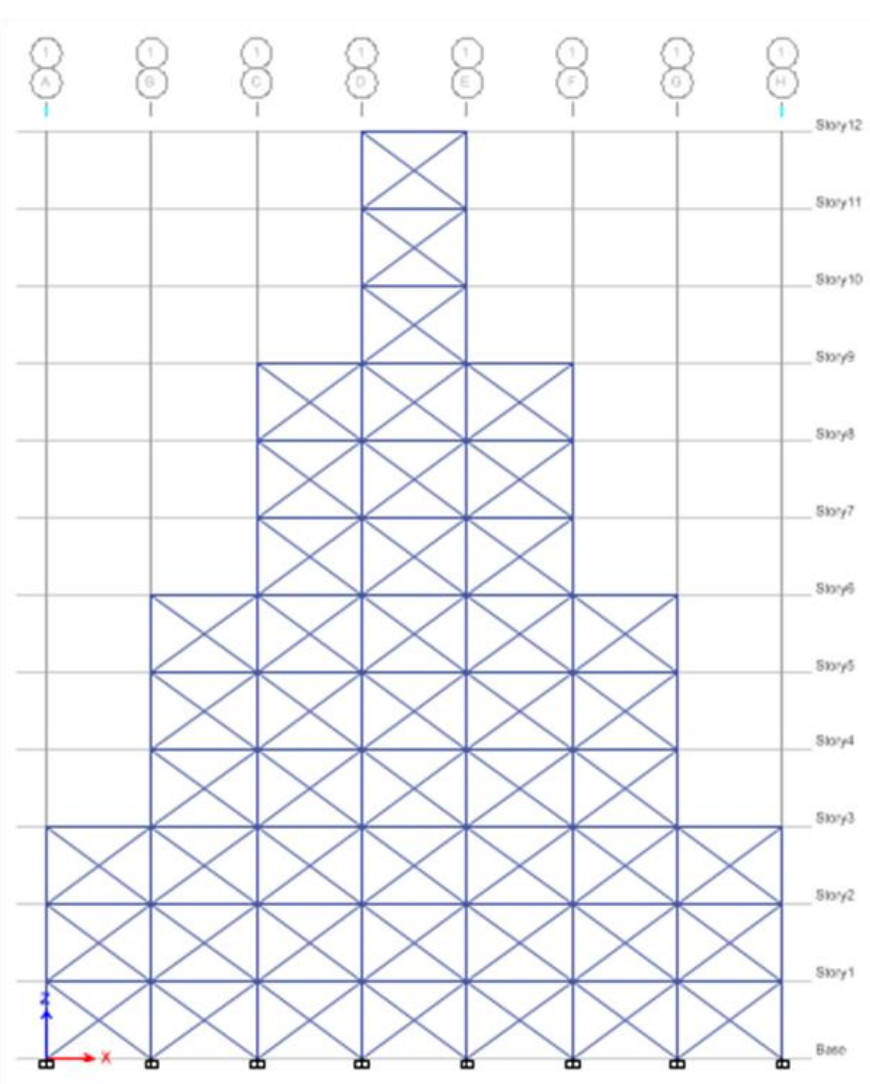

Fig. 7. Elevation of vertical geometric irregular building with masonary infill

\subsection{Modelling of masonary infill wall}

The modelling of masonary infill wall can be done by using equivalent diagonal strut. The geometric and material properties of the equivalent diagonal strut are required for conventional braced frame analysis to determine the increased stiffness of the infilled frame. The geometric properties are of effective width and thickness of the strut. The thickness and material properties of strut are similar to the infill wall. Many investigators have proposed various approximations for the width of equivalent diagonal strut. Originally proposed by Polyakov (1956) and subsequently developed by many investigators, the width of strut depends on the length of contact between the wall and the columns, $\alpha \mathrm{h}$, and between the wall and beams, $\alpha \mathrm{L}$ shown in Fig. 8. The proposed range of contact length is between one-fourth and one-tenth of the length of panel. Holmes (1963) recommended a width of the diagonal strut equal to one-third of the diagonal length of the panel. Stafford smith (1966) developed the formulations for $\alpha \mathrm{h}$ and $\alpha \mathrm{L}$ on the basis of beam on an elastic foundation. According to IS 1893(Part I): 2016, width of equivalent diagonal strut for URM infill walls without any opening shall be taken as $\mathrm{Wds}=0.175 \alpha \mathrm{h}^{-0.4} \mathrm{Lds}$

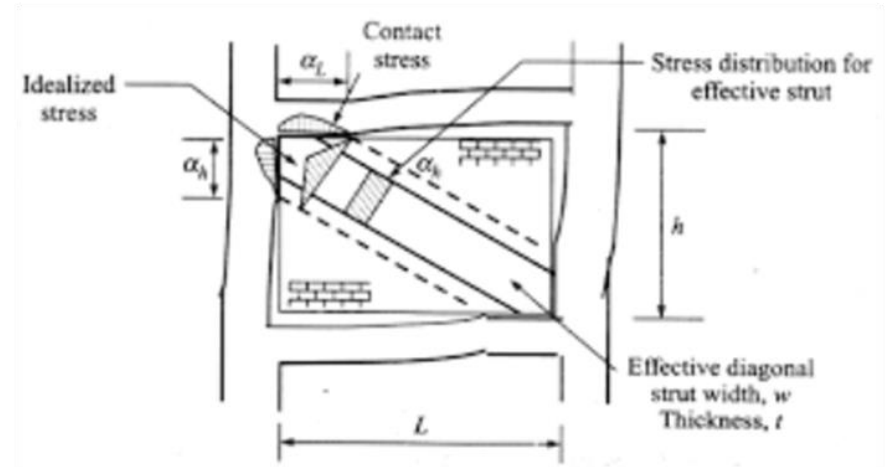

Fig. 8. Equivalent diagonal strut structure

IV. RESULTS \& DISCUSSION

Following are the results determined from the analysis:

\subsection{Pushover Analysis Result:}

\subsubsection{Performance Point}

Table -1 Performance Point of Base Shear (KN)

\begin{tabular}{|c|c|c|}
\hline Models & push x & push y \\
\hline Model 1 & 29019.7 & 25986 \\
\hline Model 2 & 37555.6 & 36370.6 \\
\hline Model 3 & 39863.9 & 33485.8 \\
\hline Model 4 & 40727.3 & 38875.7 \\
\hline Model 5 & 34578 & 35757.3 \\
\hline
\end{tabular}

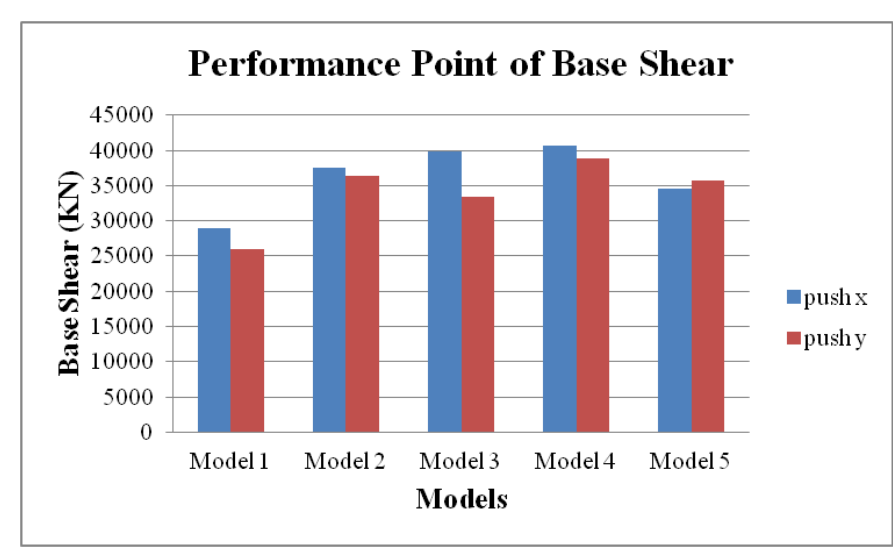

Fig. 9. Comparison of base shear of all models

By the comparison of various models it is observed that the performance point of base shear is more in mass irregular building and less in building with bare frame. The building with higher base shear has more capacity. Thus, mass irregular building has more capacity than other models and the building with bare frame has less capacity. 
Table -2 Performance Point of Displacement

\begin{tabular}{|c|c|c|}
\hline Models & push x & push y \\
\hline Model 1 & 194.11 & 231.83 \\
\hline Model 2 & 165.53 & 190.87 \\
\hline Model 3 & 166 & 174.7 \\
\hline Model 4 & 169.28 & 194.58 \\
\hline Model 5 & 146.79 & 142.38 \\
\hline
\end{tabular}

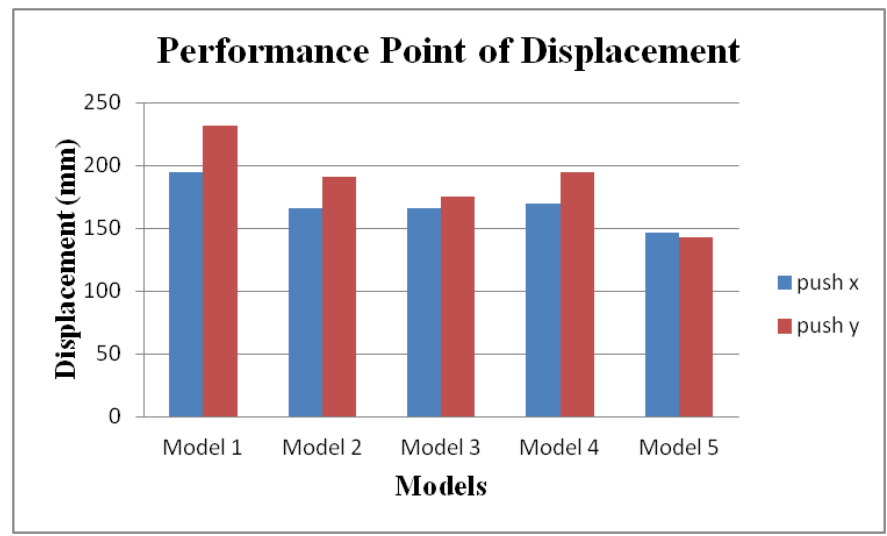

Fig. 10. Comparison of displacement of all models

The performance point of displacement is found more in bare frame building and less in vertical geometric irregular building. Thus, vertical geometric irregular building shows better performance. The building with soft storey has high value of displacement than vertical geometric irregular building and less than other models. Thus, soft storey building also shows good performance.

\subsubsection{Maximum Story Displacement}

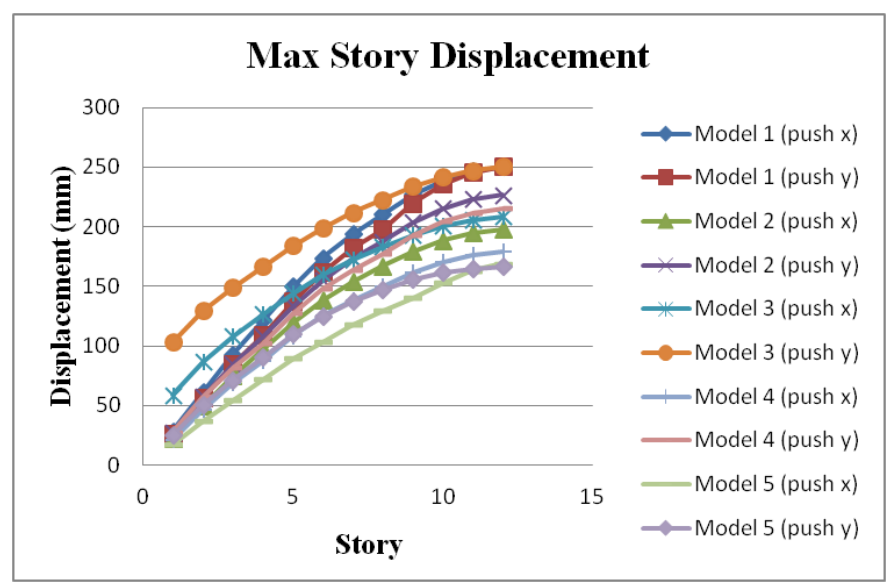

Fig. 11. Comparison of maximum story displacement of all models
From the comparison, it is observed that the maximum story displacement is more in bare frame building in both $\mathrm{x}$ and $\mathrm{y}$ directions. Vertical geometric irregular building has least value of maximum story displacement among all the models. Thus, it shows better performance.

\subsubsection{Maximum Story Drifts}

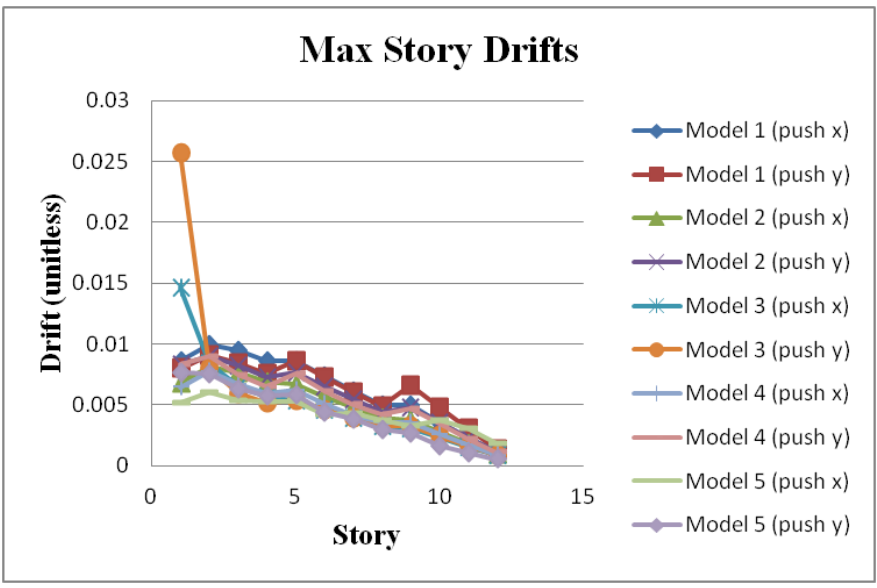

Fig. 12. Comparison of maximum story drifts of all models

Due to the discontinuity in stiffness, strength and mass, there is increase in storey drift for irregular structure. A structure having irregularity gives higher storey drift. Maximum story drifts occurs for soft storey building among all the models. Vertical geometric irregular building has least value of maximum story drifts among all the models.

\subsubsection{Story Shears}

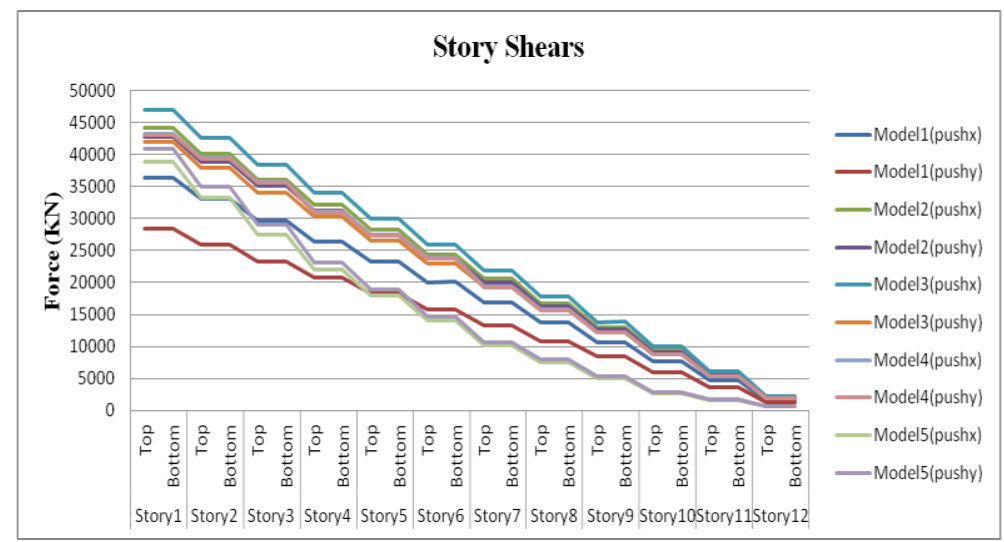

Fig. 13. Comparison of story shears of all models

After comparing the building performance, it is seen that there is increase in storey shear for masonary infilled frame building as compared to the bare frame building. Soft storey building has highest value of storey shear in $\mathrm{X}$ direction among all the models. Regular building with bare frame has least value of story shear among all the models in both the directions. 


\subsubsection{Overturning Moments}

Since overturning moments are same in $\mathrm{X}$ and $\mathrm{Y}$ direction, so only $\mathrm{X}$ direction is considered.

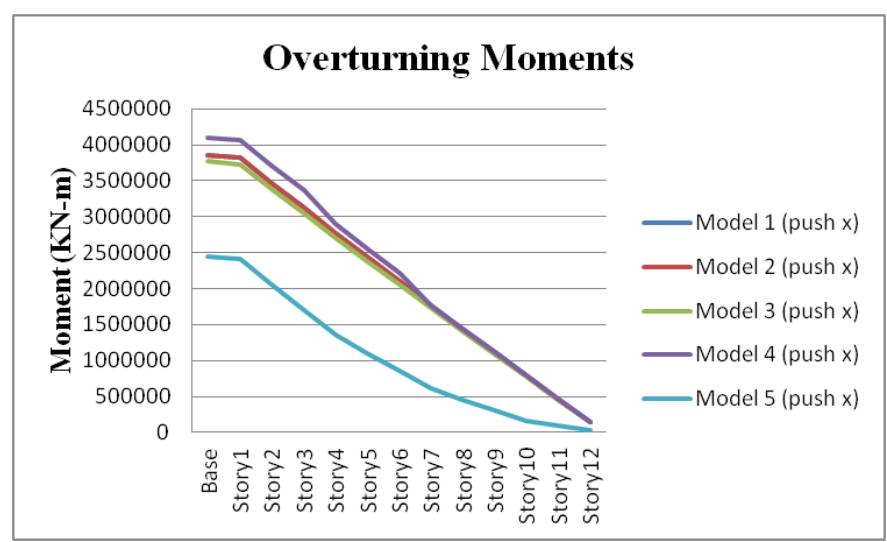

Fig. 14. Comparison of overturning moments of all models

From the comparison, it is observed that the overturning moment is maximum in mass irregular building among all the models and it is minimum in vertical geometric irregular building among all the models.

\subsection{Response Spectrum Analysis Result:}

\subsubsection{Time Period}

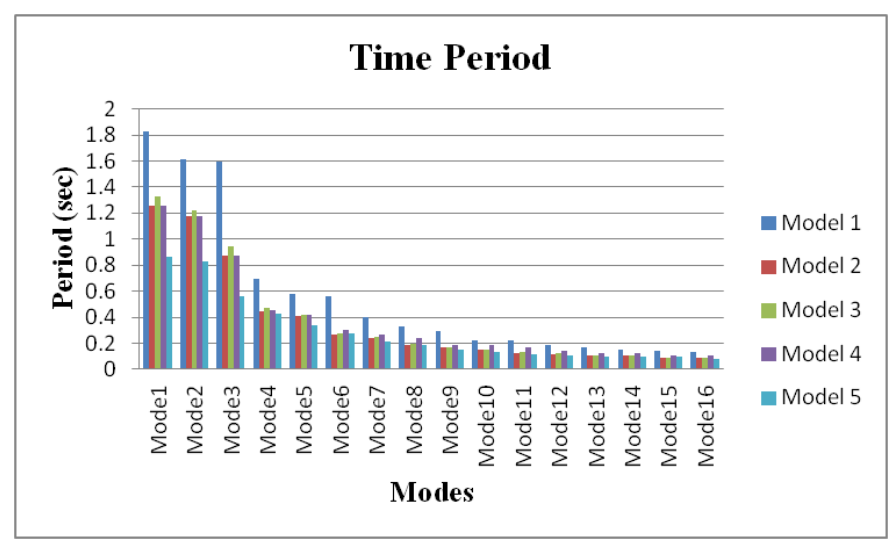

Fig. 15. Comparison of time period of all models

The time period of the structure is depends on the mass and the stiffness characteristics of the structure. Due to presence of infill in models, the stiffness increases with decreasing in time period. The time period is highest in bare frame building among all the models. Vertical geometric irregular building has least value of time period among all the models.

\subsubsection{Maximum Story Displacement}

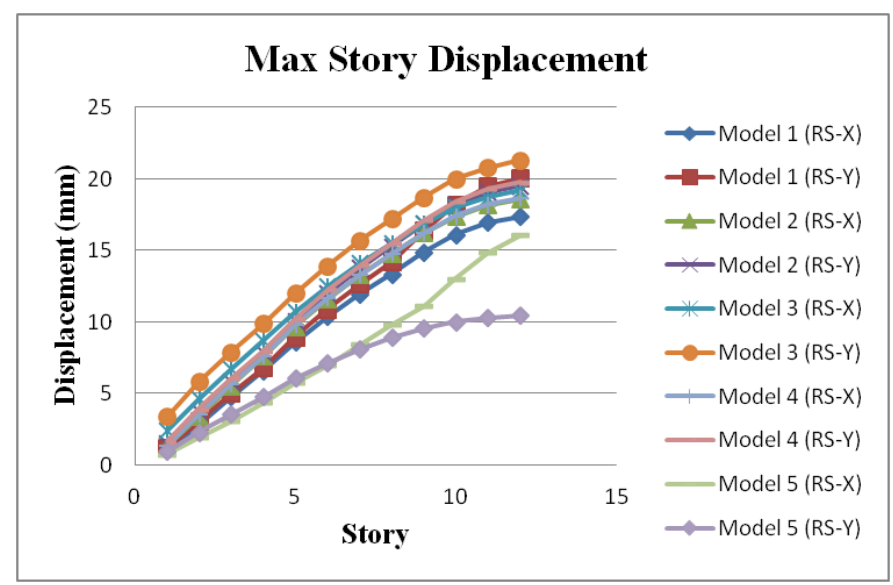

Fig. 16. Comparison of maximum story displacement of all models

From the comparison, it is observed that the soft storey building has maximum story displacement in both $\mathrm{X}$ and $\mathrm{Y}$ directions. Vertical geometric irregular building has least value of maximum story displacement among all the models in both the directions.

\subsubsection{Maximum Story Drifts}

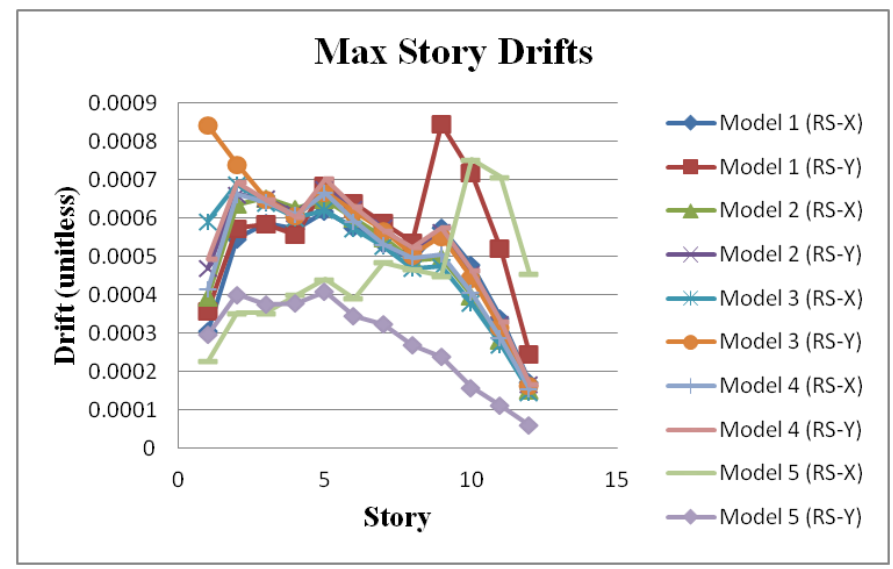

Fig. 17. Comparison of maximum story drifts of all models

From the comparison, maximum story drifts is observed in soft storey building among all the models. Vertical geometric irregular building has least value of maximum story drifts among all the models. 


\subsubsection{Story Shears}

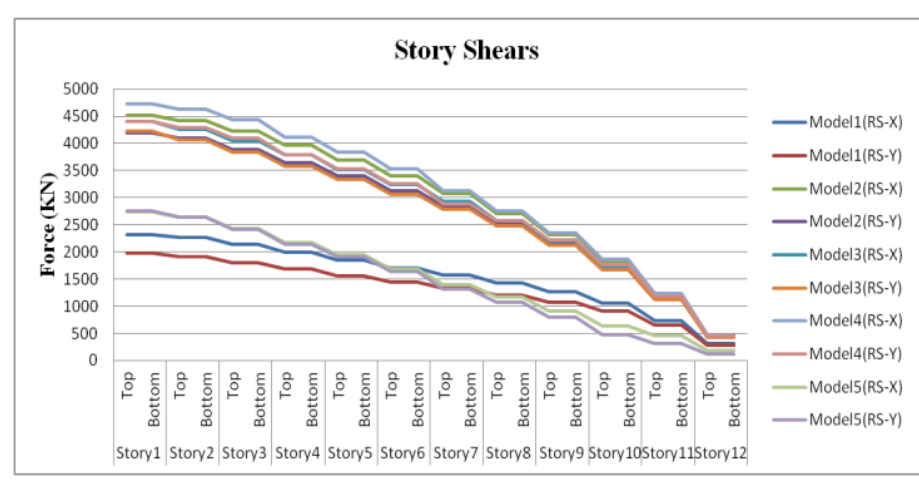

Fig. 18. Comparison of story shears of all models

After comparing the building performance, it is seen that there is increase in storey shear for masonary infilled frame building as compared to the bare frame building. Mass irregular building has highest value of storey shear among all the models and regular building with bare frame has least value of story shear among all the models.

\subsubsection{Overturning Moments}

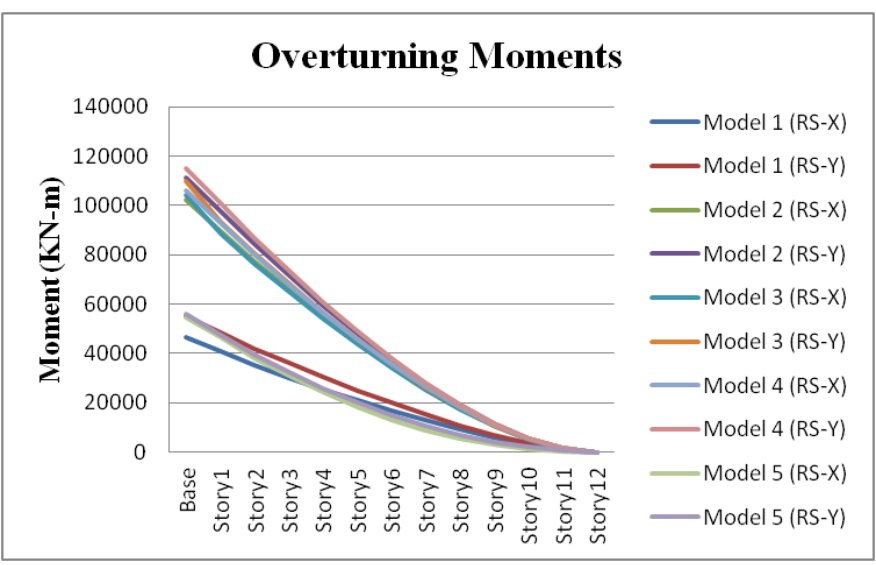

Fig. 19. Comparison of overturning moments of all models

From the comparison, it is observed that the overturning moment is maximum in mass irregular building among all the models and it is minimum in bare frame building among all the models.

\section{CONCLUSION \& FUTURE SCOPE}

\subsection{Conclusion}

\section{Pushover Analysis}

1. The performance point of base shear is highest in mass irregular building and least in bare frame building. The building with higher base shear has more capacity. Thus, mass irregular building has more capacity than other models and bare frame building has less capacity among all the models.

2. The performance point of displacement is highest in bare frame building and least in vertical geometric irregular building. Thus, vertical geometric irregular building shows better performance. The building with soft storey also has less value of displacement. Thus, soft storey building also shows good performance.

3. The maximum story displacement occurs in bare frame building in both $\mathrm{X}$ and $\mathrm{Y}$ directions. Vertical geometric irregular building has least value of maximum story displacement among all the models. Thus, it shows better performance.

4. Maximum story drifts occurs for soft storey building among all the models. Vertical geometric irregular building has least value of maximum story drifts among all the models.

5. After comparing the building performance, it is seen that there is increase in storey shear for masonary infilled frame building as compared to the bare frame building. Soft storey building has highest value of storey shear in X direction among all the models. Regular building with bare frame has least value of story shear among all the models in both the directions.

6. The overturning moment is maximum in mass irregular building among all the models and it is minimum in vertical geometric irregular building among all the models.

\section{Response Spectrum Analysis}

1. Due to presence of infill in models, the stiffness increases with decreasing in time period. The time period is highest in bare frame building among all the models. Vertical geometric irregular building has least value of time period among all the models.

2. From the comparison, it is observed that the soft storey building has maximum story displacement in both $\mathrm{X}$ and $\mathrm{Y}$ directions. Vertical geometric irregular building has least value of maximum story displacement among all the models in both the directions.

3. From the comparison, maximum story drifts is observed in soft storey building among all the models. Vertical geometric irregular building has least value of maximum story drifts among all the models.

4. From the comparison, it is observed that the mass irregular building has highest value of storey shear among all the models and regular building with bare frame has least value of story shear among all the models.

5. The overturning moment is maximum in mass irregular building among all the models and it is minimum in bare frame building among all the models. 


\section{International Journal of Engineering Applied Sciences and Technology, 2021 \\ Vol. 5, Issue 12, ISSN No. 2455-2143, Pages 112-121 \\ Published Online April 2021 in IJEAST (http://www.ijeast.com)}

From the analysis results, it has been concluded as follows:

- Vertical geometric irregular building shows better performance under seismic loading and bare frame building shows inferior performance.

- The performance of masonary infilled frame building is better than bare frame building.

- The infill walls reduce displacements, time period and increases base shear. So it is essential to consider the effect of masonry infill for the seismic evaluation of moment resisting reinforced concrete frame.

\subsection{Future Scope}

1. In the present study moderate seismic zone is considered for the analysis, further study can be carried out for high seismic zones.

2. Similar studies can be carried out for different infills such as shear wall.

\section{REFERENCE}

[1] Agrawal, P. and Shrikhande, M. (2015). "Earthquake Resistant Design of Structures", Delhi: Rajkamal Electric Press.

[2] Anwaruddin, M. D., Akberuddin, M. D., Zameeruddin, M. D., \& Saleemuddin, M. D. (2013). "Pushover Analysis of Medium Rise Multi-Story RCC Frame With and Without Vertical Irregularity". International Journal of Engineering Research and Applications, ( pp. 540-546).

[3] Athanassiadou, C. J. (2007). "Seismic Performance of $\mathrm{R} / \mathrm{C}$ Plane Frames Irregular in Elevation". Engineering Structures, (pp. 1250-1261).

[4] Baghi, H., Oliveira, A., Valenca, J., Cavaco, E., Neves, L., \& Julio, E. (2018). "Behavior of Reinforced Concrete Frame With Masonry Infill Wall Subjected to Vertical Load". Engineering Structures, (pp. 476-487).

[5] Bari, M. A., \& Abdulla, S. (2016). "Linear and Non Linear (Pushover) Analysis of An Irregular Shape Multistorey Building with Different Shear Wall Position". International Journal of Engineering Research \& Technology, (pp. 468-475).

[6] Chandrahas, B. L., \& Raju, P. P. (2017). "Behaviour of Soft Storey RC Framed Building Under Seismic Loading”. International Journal of Civil Engineering and Technology, (pp. 265-277).

[7] Choudhary, M. S., Arfath, S., Ahmed, M. M., \& Pasha, N. (2018). "Comparative Study on Seismic Analysis of Multi Storey Building Having Diaphragm Discontinuity Using
Etabs". International Journal of Research in Advent Technology, (pp. 912-918).

[8] Cimellaro, G. P., Giovine, T., \& Garcia, D. L. (2014). "Bidirectional Pushover Analysis of Irregular Structures". Journal of Structural Engineering, vol. 140.

[9] Criteria for Earthquake Resistance Design of Structures, IS 1893:2016(1), Bureau of Indian Standards, New Delhi.

[10] Ductile Design and Detailing of Reinforced Concrete Structures Subjected to Seismic Forces- Code of Practice, IS 13920:2016, Bureau of Indian Standards, New Delhi.

[11] Farhan, M. A. A., \& Bommisetty, J. (2019). "Seismic Analysis of Multistoried RCC Buildings Regular and Irregular in Plan". International Journal of Engineering Research \& Technology, (pp. 115-121).

[12] Firoj, M., \& Singh, S. K. (2018). "Response Spectrum Analysis for Irregular Multi-Storey Structure in Seismic Zone V'. In 16th Symposium on Earthquake Engineering, IIT Roorkee, India.

[13] Hassaballa, A. E., Adam, F. M., \& Ismaeil, M. A. (2013). "Seismic Analysis of a Reinforced Concrete Building by Response Spectrum Method". IOSR Journal of Engineering, (pp. 1-9).

[14] Improvement of Nonlinear Static Seismic Analysis Procedures, FEMA 440 Applied Technology Council, Redwood City, California.

[15] Irfan, M. D., Reddy, S., \& Mythili, K. (2014). "Evaluation of Seismic Response of Symmetric and Asymmetric Multistoried Buildings". International Journal of Science Engineering and Advance Technology, (pp. 505-509).

[16] Mahdi, T., \& Bahreini, V. (2013). "Seismic Response of Asymmetrical Infilled Concrete Frames". Procedia Engineering, (pp. 341-352).

[17] Manju, G. (2014). "Dynamic Analysis of Infills on R.C Framed Structures". International Journal of Innovative Research in Science, Engineering and Technology, (pp. 16150-16158).

[18] Oinam, R. M., Sugumar, R., \& Sahoo, D. R. (2017). “A Comparative Study of Seismic Performance of RC Frames with Masonry Infills". Procedia Engineering, (pp. 1784-1791).

[19] Patel, C., Patel, P., \& Thaker, G. (2018). "Pushover Analysis of High Rise RCC Building with Vertical Irregularities". International Journal of Advance Engineering and Research Development, (pp. 13-19).

[20] Pathi, N. L., Guruprasad, T. N., Dharmesh, N., \& Madhusudhana, Y. B. (2015). "Static Linear and NonLinear (Pushover) Analysis of Multi Storey RC Frame with and without Vertical Irregularities". International Journal for Scientific Research \& Development, (pp. 245250). 
[21] Prakash, T. M., Kumar, B. G. N., Punith, N., \& Mallamma (2017). "Seismic Analysis of Multi-Storeyed Building Having Vertical Irregularities Using Pushover Analysis". International Journal of Innovative Research in Science, Engineering and Technology, (pp. 9340-9347).

[22] Prestandard and Commentary for the Seismic Rehabilitation of Buildings, FEMA 356 American Society of Civil Engineers, Virginia.

[23] Sadjadi, R., Kianoush, M. R., \& Talebi, S. (2007). "Seismic Performance of Reinforced Concrete Moment Resisting Frames". Engineering Structures, (pp. 23652380).

[24] Seismic Evaluation and Retrofit of Concrete Buildings, Volume 1 ATC-40, Applied Technology Council, Redwood City California.

[25] Shrivastava, D., \& Bhaduria, S. S. (2017). "Analysis of Multi-Storey RCC Frames of Regular and Irregular Plan Configuration using Response Spectrum Method". SSRG International Journal of Civil Engineering, (pp. 70-78).

[26] Srimukha, K., \& Bantupalli, R. (2016). "Pushover Analysis of Multi-Storey RCC Frame with and without Vertical Irregularities". International Journal of Engineering and Management Research, (pp. 20-25).

[27] Tidke, K., \& Jangave, S. (2016). "Seismic Analysis of Building with and without Infill Wall". International Journal of Innovative Research in Science, Engineering and Technology, (pp. 12646-12652).

[28] Totiger, K., \& Bastwadkar, M. (2020). "Comparative Study of Static and Dynamic Method of Seismic Analysis of RCC Multistoried Building". International Research Journal of Engineering and Technology, (pp. 1939-1943).

[29] Tsige, G. Z., \& Zekaria, A. (2018). "Seismic Performance of Reinforced Concrete Buildings with Masonry Infill". American Journal of Civil Engineering, (pp. 24-33).

[30] Wakchaure, M. R., \& Ped, S. P. (2012). "Earthquake Analysis of High Rise Building with and without Infilled Walls". International Journal of Engineering and Innovative Technology, (pp. 89-94). 